\title{
O contato do português com as línguas indígenas brasileiras: considerações sobre o desenvolvimento de L2
}

\author{
The contact of Portuguese with Brazilian indigenous languages: \\ considerations on the development of L2
}

\author{
Jaqueline dos Santos Peixoto ${ }^{1}$ \\ https://orcid.org/0000-0002-4083-2456
}

DOI: $10.26512 /$ rbla.v12i1.29723

Recebido em março/2020 e aceito em maio/2020

\section{Resumo}

Nosso objetivo neste artigo é contar uma parte da história do português do Brasil a partir do contato com as línguas indígenas nacionais. Para realizar esse objetivo, buscamos trabalhos que versam sobre a presença real de características gramaticais e sonoras das línguas dos povos indígenas no português falado pelos membros desses povos. A interferência das gramáticas nativas dos povos indígenas é discutida a partir de propriedades sonoras consonantais e vocálicas do português ticuna (Bonifácio 2019); de propriedades consonantais do português camaiurá (Silva e Silva 1985); de propriedades gramaticais dos subsistemas da flexão de número no nome e da flexão de primeira e terceira pessoa do plural no verbo do português xinguano (Emmerich 1987); e de características gramaticais da expressão do gênero no português huni kuin (Christino 2015). Defendemos que compreender o conhecimento linguístico responsável por produzir as características do português de contato com as línguas indígenas brasileiras possa esclarecer fenômenos envolvidos no processo de bilinguismo/multilinguismo dos povos indígenas, e ajudar a lidar com os desafios da educação escolar indígena. Para explicar o comportamento linguístico e mostrar como ele se apoia nas propriedades da Faculdade da Linguagem, recorremos ao conceito de interlíngua (Selinker 1972). Partindo desse conceito, o início do processo de conhecimento de L2 seria marcado pela presença da gramática nativa e pelos dados da segunda língua. Todo esse processo seria restringido pelas propriedades gerais e abstratas da linguagem humana (White 2003). Assim, buscamos demonstrar como as gramáticas nativas estruturam o português de contato. Pretendemos com o reconhecimento dessa estruturação um resgate da participação da língua e cultura dos povos nativos na sociedade brasileira, e uma promoção do seu processo de decolonização.

Palavras-chave: Contato linguístico, línguas indígenas, português do Brasil, educação indígena, segunda língua.

1 Linguista, Professora Associada II do Departamento de Letras Vernáculas da Faculdade de Letras da UFRJ da Universidade Federal do Rio de Janeiro. E-mail: jaquepeixoto@, yahoo.com. 


\begin{abstract}
Our aim in this article is to tell a part of Brazilian Portuguese history through the contact with national indigenous languages. In order to achieve this objective, we have sought works which deal with the presence of grammatical and sound characteristics of the native languages in the Portuguese spoken by the indigenous communities members. Native grammars interference is discussed based on consonant and vowel sound properties of Ticuna Portuguese (Bonifácio 2019); consonant properties of Camaiurá Portuguese (Silva e Silva 1985); grammatical properties of the nominal number inflection and of the verbal inflection for first and third persons plural forms of Xinguano Portuguese (Emmerich 1987); and grammatical characteristics of gender expression in Huni Kuin Portuguese (Christino 2015). We argue here that the understanding of the linguistic knowledge responsible for the characteristics observed in the Portuguese developed from the contact with Brazilian indigenous languages can help clarify the phenomena involved in the bilingualism / multilingualism process, and can also help to deal with the challenges of indigenous school education. In order to explain the linguistic behavior identified and to show how it relies on the sources of the Language Faculty, we have adopted the concept of Interlanguage (Selinker 1972). Based on this concept, we can assume that the beginning of L2 knowledge would be marked by the presence of native grammars (L1s) and the input data of the targetlanguage. This entire process would be restricted by the general and abstract properties of the Human Language Faculty (White 2003). Thus, we aim to show how Brazilian native grammars structure contact Portuguese. Through the recognition of this structuring, we intend to rescue the participation of native peoples languages and cultures in Brazilian society and a promotion of their decolonization process.
\end{abstract}

Keywords: Language contact, indigenous languages, Brazilian Portuguese, indigenous education, second language.

\title{
1. Introdução
}

A história do português no território nacional brasileiro precisa ser contada a partir do contato entre as línguas dos povos nativos e daqueles vindos de fora. A situação linguística do português no início da colonização e o seu contato com as línguas indígenas e as línguas africanas levaram alguns pesquisadores a procurar identificar na língua falada no Brasil características de um crioulo de base lexical portuguesa e gramática africana ${ }^{2}$. Diferentes autores buscaram explicar as características do português popular do Brasil a partir de um crioulo de base lexical portuguesa e gramática africana (Coelho 1967; Guy 1989, 1981a, 1981b; Jeroslow 1975) ${ }^{3}$. Mas ainda são escassos os trabalhos que discutem o papel do contato do português com as línguas indígenas brasileiras (Bonifácio 2019; Peixoto 2017a; Christino 2015; Emmerich 1987, 1984; Silva e Silva 1985 etc.). A ideia geral é a de que as línguas indígenas brasileiras contribuíram com

2 Mais atualmente, pesquisadores têm se interessado por investigar a presença de variedades crioulas no português quilombola, ou seja, no português falado por comunidades rurais afro-brasileiras que se mantiveram isoladas.

3 Outra hipótese é a que considera o português do Brasil como o resultado da convergência entre uma deriva urbana e outra rural. 
alguns empréstimos lexicais, que logo foram assimilados às regras gramaticais da língua nacional.

Acreditamos que, ao contrário do que o português símbolo de unidade nacional e homogeneidade linguística, representado no inconsciente coletivo faça imaginar, é possível rastrear sim a presença real da língua / cultura indígena na identidade nacional. Para nós, as evidências da presença real da língua / cultura dos povos indígenas em nossa língua são fornecidas pelo próprio português falado por esses povos. A apropriação do português pelo elemento indígena inaugura uma nova etapa na história dessa língua. A investigação das características do português indígena e a sua participação em fenômenos variáveis populares do português do Brasil (PB) continuam a ser um fato inédito para o estudo da linguagem como uma ciência da cognição. $\mathrm{O}$ estudo da linguagem como uma ciência da cognição pretende revelar como o conhecimento das línguas particulares atuaria na determinação da forma e do significado intrínseco às expressões linguísticas. Com base na concepção da linguagem como uma ciência da cognição humana, acreditamos que o estudo do português indígena possa iluminar questões relativas à criação das representações abstratas pelo cérebro, mostrando como o pensamento humano é transformado em sinais articulados e organizados estruturalmente. O repertório do comportamento verbal de falantes de diferentes etnias pode ser explicado com base nos aspectos significativos desse repertório e nos princípios sobre os quais esses aspectos se organizam.

Cabe hoje à língua portuguesa atender às demandas de diferentes grupos étnicos, transformando-se em instrumento de pensamento e ação. Nesse sentido, é importante esclarecer que o termo português indígena não se refere a uma variedade única, particular e homogênea do português. Trata-se, antes, de uma apropriação do PB pelos povos indígenas brasileiros. A forma como ocorre tal apropriação e suas características revelam uma situação de contato linguístico. $\mathrm{O}$ contato linguístico representa uma situação em que línguas ou variedades diferentes de uma mesma língua estão geográfica ou socialmente próximas. A proximidade linguística costuma ter como resultados o empréstimo linguístico e a interferência linguística.

Este nosso trabalho tem como objetivo mostrar como pesquisadores brasileiros atendem ao desafio de revelar como características gramaticais e sonoras das línguas indígenas brasileiras estão presentes nas variedades do português indígena. Como objetivos associados estão iluminar os mecanismos presentes no desenvolvimento de $\mathrm{L}^{4}$, e entender os desafios que o contato do português com as línguas dos primeiros povos traz para a educação escolar indígena.

4 Os termos L1 e L2 são usados neste trabalho para se referirem, respectivamente, à língua nativa e estrangeira. 


\section{Mecanismos do desenvolvimento de L2}

O contato entre as línguas dos povos indígenas e o português cria a uma situação linguística em que os falantes indígenas são levados a utilizar alternadamente línguas diferentes, conforme as diferentes situações de interação social. No Brasil, país em que o português é a língua oficial nacional, os grupos indígenas utilizam suas línguas maternas nas atividades da vida cotidiana, mas, em situações formais e públicas, são levados a utilizar a língua do Estado. O próprio bilinguismo muitas vezes decorre de uma situação de multilinguismo, devido à proximidade geográfica ou social entre diferentes povos indígenas. A situação de multilinguismo está presente, por exemplo, no Parque Nacional do Xingu (MT) e na região do Alto Rio Negro (AM).

Apesar dos seus aspectos sociais, o bilinguismo costuma ser tratado como um fenômeno individual. O bilinguismo individual corresponde ao domínio correto de uma língua estrangeira ao lado da língua materna. No bilinguismo, o falante bilíngue ideal é concebido como aquele que possui domínio nativo igual da gramática de duas línguas (Bloomfield 1933). Essa concepção de bilinguismo exclui a grande maioria dos falantes bilíngues adultos, cujo domínio da segunda língua, da qual não são falantes nativos, costuma sofrer interferência da primeira língua, da qual são falantes nativos. A interferência de uma gramática na outra mostra que, no bilinguismo adulto, o falante bilíngue ideal é, na verdade, uma ficção. A proficiência linguística na língua estrangeira, ou seja, a capacidade de falar outra língua, dos indivíduos bilíngues adultos está sujeita a interferências de condições de diferentes naturezas.

No bilinguismo adulto, o que deve entrar em discussão é o grau de controle das gramáticas das duas línguas e as situações de comunicação linguística em que ocorrem os usos das línguas em contato. No primeiro caso, são relevantes as propriedades gramaticais responsáveis pela formulação linguística da mensagem, e as características fonológicas responsáveis pela articulação sonora dos enunciados linguísticos. No segundo caso, são relevantes os espaços sociais onde ocorre a utilização das duas línguas, e as situações em que os falantes se tornam bilíngues.

A competência linguística do falante bilíngue adulto é mostrada pela sua capacidade de falar outra língua e pelo controle das duas gramáticas. A capacidade de falar outra língua e o seu controle gramatical são observados por meio da investigação dos componentes gramaticais (sintaxe e morfologia) e sonoro (fonologia). O componente gramatical é responsável pelo processo cognitivo de acessar, ordenar e ajustar as palavras aos seus ambientes gramaticais, enquanto o componente sonoro é responsável por acessar, ordenar e ajustar os sons aos seus ambientes fonológicos. Cabe ao componente gramatical a formulação da mensagem, e ao componente sonoro a sua articulação. Ambos 
os componentes são responsáveis por acessar a informação linguística que transforma pensamento em linguagem.

$\mathrm{O}$ bilinguismo individual tem como característica ser um fenômeno dinâmico. A dinamicidade do bilinguismo individual se releva pelas mudanças que ocorrem em relação à competência linguística do indivíduo ao longo de sua trajetória, e pelas variações do desempenho individual nas situações de uso de duas línguas (Heye 1999). A compreensão da evolução do bilinguismo passa pelo conceito de interlíngua. Esse conceito é introduzido por Selinker (1969), e desenvolvido por Selinker (1972), para explicar o fato de os enunciados linguísticos produzidos pelos aprendizes de línguas estrangeiras não refletirem as propriedades gramaticais e fonológicas existentes na língua alvo ${ }^{5}$ Selinker propõe a existência de um sistema linguístico diferente da língua nativa e da língua alvo, baseando-se na observação das formas linguísticas produzidas pelo aprendiz. A esse terceiro sistema, chama de interlíngua. No âmbito do Programa de Estudos da Linguagem da Gramática Gerativa, a interlíngua é restringida pelos princípios e parâmetros da Gramática Universal $(\mathrm{GU})^{6}$. Isso quer dizer que as propriedades gramaticais observadas na interlíngua refletem propriedades gerais da linguagem humana.

O conceito de interlíngua não serve para explicar apenas o comportamento verbal individual dos falantes não nativos de uma segunda língua. A interlíngua também tem seu papel na gramática da variedade de contato. A persistência de elementos linguísticos, regras, subsistemas gramaticais e sonoros entre falantes nativos da mesma língua na produção linguística da interlíngua pode fazer emergir um novo dialeto. Os novos dialetos ou variedades surgidos de situações de contato linguístico têm como característica ser um fenômeno sociodialetal relativamente estático.

No estágio inicial do desenvolvimento da interlíngua, estão presentes o conhecimento da gramática nativa dos falantes e os dados da língua estrangeira. No processo de desenvolvimento de L2, a gramática da interlíngua passa por processos de estruturação e reestruturação gramatical e sonora. As propriedades da gramática da variedade de contato são investigadas por meio das características gramaticais e sonoras presentes no comportamento verbal não nativo de um grupo de indivíduos falantes de duas línguas. O comportamento verbal não nativo pode ser resultado dos seguintes processos: (a) transferência de elementos linguísticos, regras, subsistemas gramaticais e sonoros da L1 na variedade de contato, evidenciada pela ocorrência de propriedades superficiais da língua nativa na língua estrangeira; (b) supergeração de elementos

5 No processo de desenvolvimento do conhecimento de L2, o termo língua alvo se refere à língua estrangeira.

6 A GU é uma teoria do Estado Inicial de aquisição da linguagem (Chomsky 2001, 1995, 1965). 
linguísticos, regras, subsistemas gramaticais e sonoros na variedade de contato, evidenciada pela ocorrência de estruturas e processos sonoros tanto gramaticais quanto agramaticais, estes últimos aparecendo em contextos em que efetivamente não se aplicariam, causando a supergeração de estruturas não gramaticais no sistema alvo; e (c) surgimento de novos elementos linguísticos, regras, subsistemas gramaticais e sonoros diferentes de L1 e L2, evidenciado pela presença de estruturas e elementos sonoros ausentes na gramática da língua em contato (Selinker 1972).

O conceito de interlíngua mostra alguns consensos acerca o desenvolvimento do conhecimento de uma gramática não nativa. Pesquisadores ${ }^{7}$ parecem concordar que o início da aprendizagem de L2 possa ser marcado por algum tipo de interferência de L1. Outro consenso é a reestruturação da gramática da interlíngua ao longo do processo de desenvolvimento do conhecimento de L2. O dissenso está justamente no que diz respeito ao papel ${ }^{8}$ da Gramática Universal ao longo desse processo de desenvolvimento de conhecimento. Tal dissenso, contudo, não pode ser usado como argumento contrário às evidências de que o processo de desenvolvimento do conhecimento da gramática da língua estrangeira seja estruturado pelo conhecimento gramatical e sonoro da língua nativa. Mostrar como a gramática do português de contato (PC) com as línguas indígenas brasileiras é estruturada ao longo do seu desenvolvimento é o objetivo deste trabalho. Compreender a estruturação do português falado pelos indígenas brasileiros é fundamental para entendermos as demandas impostas pela educação escolar indígena.

\section{O português de contato com as línguas indígenas}

A seção anterior mostrou que as variedades de contato podem tanto significar uma nova variedade linguística, na medida em que caracterizam o comportamento verbal relativamente estático dos membros de uma comunidade, quanto uma variedade em transição, na medida em que caracterizam o comportamento verbal dinâmico de indivíduos ocorrido ao longo do processo de desenvolvimento do conhecimento de outra língua. O português de contato, que se refere ao uso feito do português do Brasil por indivíduos de diferentes grupos étnicos, tem suas características linguísticas moldadas pelas demandas feitas por indivíduos ou grupos de diferentes identidades étnicas. Para compreendermos como a língua nacional atende às demandas feitas por esses novos falantes tratamos nesta

7 Ver mais a respeito em White (2003).

8 Pesquisadores se dividem quanto às hipóteses de acesso à GU no desenvolvimento do conhecimento de uma língua estrangeria (cf. Sauter (2002)). Não discutimos essas hipóteses aqui porque nosso foco está na participação da gramática nativa das línguas dos povos indígenas na estruturação da gramática do português de contato, e não na GU. 
seção das características gramaticais e sonoras identificadas por pesquisadores brasileiros no português indígena.

$\mathrm{O}$ português indígena, que surge do contato do $\mathrm{PB}$ com as línguas dos primeiros povos do Brasil, tem despertado a atenção de pesquisadores nos últimos tempos. Contudo, dada a diversidade de línguas com as quais a língua nacional entra em contado, é possível dizer que ainda são poucos os trabalhos que discutem o papel do contato do português com as línguas indígenas brasileiras (Bonifácio 2019; Peixoto 2017a; Christino 2015; Emmerich 1987, 1984; Silva e Silva 1985 etc.). As características estruturais e sonoras da gramática do português de contato com as línguas indígenas brasileiras são reveladas nos trabalhos de pesquisadores que têm se interessado pelo tema. Características sonoras e gramaticais do português ticuna são registradas por Bonifácio (2019). Silva e Silva (1985) identificam características sonoras consonantais do português camaiurá. Emmerich (1987) revela propriedades gramaticais dos subsistemas da flexão de número no nome e da flexão de primeira e terceira pessoa do plural no verbo. Finalmente, Christino (2015) trabalha com características gramaticais da expressão do gênero no português huni kuin. A compreensão dessas características pode ser reveladora das propriedades da gramática de contato, fornecer informações para o debate em torno dos mecanismos presentes no desenvolvimento de L2, e ajudar a lidarmos com os desafios da educação escolar indígena, no que diz respeito ao ensino de português.

\subsection{Considerações sobre aspectos da gramática do português indígena a partir do contato linguístico}

Os resultados dos trabalhos a respeito do português indígena podem esclarecer as características do conhecimento de L2, por meio da presença dos mecanismos de transferência linguística, supergeração linguística e geração de novos elementos sonoros e gramaticais que podem surgir da situação de contato do português brasileiro com as línguas dos primeiros povos. Com a identificação desses mecanismos, pretendemos revelar a natureza do conhecimento linguístico dos falantes em jogo no desenvolvimento de outra língua. Acreditamos que a identificação desse conhecimento possa explicar os dispositivos que levam à decisão sobre qual gramática seguir.

\subsection{O português indígena ticuna}

A língua do povo ticuna, que recebe o mesmo nome da denominação étnica, é classificada como isolada, ou seja, é o único membro da sua família (Rodrigues 1994). A língua ticuna é falada por uma população encontrada no Brasil, Peru e Colômbia. No Brasil, possui uma população de cerca de 46, 1 mil indivíduos. Correspondendo a $6,8 \%$ da população indígena brasileira, é a etnia com maior 
número de pessoas (IBGE 2010). Em território nacional, a população ticuna é encontrada em municípios do Estado do Amazonas. Bonifácio (2019) faz um registro e busca apresentar uma caracterização da variedade do português de contato falada por professores da educação básica pertencentes a essa etnia. A caracterização da variedade do português de contato ocorre por meio de um levantamento de aspectos fonético-fonológicos, morfológicos e sintáticos observados nas produções linguísticas de professores ticunas que, atuando na educação básica, forneceram os dados para a constituição da amostra da autora. Nosso interesse está nas propriedades do sistema sonoro consonantal e vocálico do português ticuna descritas por Bonifácio.

Um estudo acerca dos sistemas consonantal e vocálico da língua ticuna é apresentado em Soares (1995). Um quadro fonológico das consoantes da língua é proposto por nós a seguir, em (i), com base nesse estudo de Soares.

\section{(i) Consoantes fonológicas da língua ticuna}

\begin{tabular}{|c|c|c|c|c|c|}
\hline & \multirow[t]{2}{*}{ Labial } & \multicolumn{2}{|c|}{ Coronal } & \multirow[t]{2}{*}{ Dorsa } \\
\hline & & & [+anterior $]$ & [-anterior] & \\
\hline \multirow[t]{3}{*}{ [-contínuo] } & [-sonoro] & $\mathrm{p}$ & $\mathrm{t}$ & ts & $\mathrm{k}$ \\
\hline & [+sonoro] & $\mathrm{b}$ & d & $\mathrm{dz}$ & $\mathrm{g}$ \\
\hline & {$[+$ nasal $]$} & $\mathrm{m}$ & $\mathrm{n}$ & $\mathrm{n}$ & $y$ \\
\hline \multirow[t]{2}{*}{ [+contínuo] } & [-aproximante] & & $\mathrm{f}$ & & \\
\hline & [+aproximante] & $\mathrm{W}$ & & & \\
\hline
\end{tabular}

Nosso objetivo com o quadro acima é evidenciar algumas diferenças entre os sistemas fonológicos do ticuna e do português do Brasil. O sistema fonológico de consoantes do português se caracteriza entre outros aspectos por possuir oposição entre obstruintes não contínuas /p, b, t, d, k, g/ e contínuas /f, v, s, z, $\int$, z/; e vibrantes $/ \mathrm{r}^{9}, \mathrm{r} / \mathrm{e}$ não vibrante $/ 1 /$. Diferentemente, a língua ticuna não possui em seu sistema consonantal oposição entre obstruintes não contínuas $/ \mathrm{p}$, $\mathrm{b}, \mathrm{t}, \mathrm{d}, \mathrm{ts}, \mathrm{dz}, \mathrm{k}, \mathrm{g} / \mathrm{e}$ contínuas, estas últimas ausentes do sistema fonológico. A ausência de consoantes obstruintes contínuas cria lacunas no sistema fonológico de consoantes do ticuna, quando comparado com o sistema do português. Também chama nossa atenção a presença das africadas fonológicas /ts, dz/ no sistema de consoantes da língua. As duas africadas se opõem entre si pela sonoridade ([-sonoro] e [+sonoro]) e entre as demais consoantes obstruintes não contínuas pela região onde ocorre a constrição na cavidade oral ([-anterior] e [+anterior]). A presença da consoante aproximante labial-dorsal /w/ é outro fato próprio da fonologia consonantal ticuna. A oposição entre consoantes vibrantes

9 Esclarecemos que estamos tomando como representante fonológico do chamado erreforte do PB a vibrante múltipla /r/. 
e a não vibrante, presente no português do Brasil, também não está presente no sistema de consoantes do ticuna.

As lacunas que a ausência de oposições presentes no português do Brasil (PB) provoca no sistema do ticuna têm consequências sobre o português ticuna (PT), ou seja, no português de contato com a língua indígena, como mostram os dados de Bonifácio (2019), em (1), a seguir:

(1)

\begin{tabular}{|c|c|c|c|}
\hline PB & PT & Ocorrências & Fenômeno \\
\hline $\mathrm{s}, \int$ & $\mathrm{s}$ & $\begin{array}{c}\text { ro[s]a 'roça' } \\
\text { [s]amou 'chamou }\end{array}$ & \\
\hline $\mathrm{z}, 3$ & $\mathrm{z}$ & $\begin{array}{c}\text { fi[z]ica 'física' } \\
\text { via[z]]em 'viagem' }\end{array}$ & $\begin{array}{c}\text { posteriorização } \\
\text { (Bonifácio 2019) }\end{array}$ \\
\hline $\int$ & $\mathrm{s}$ & ro[s]a 'rocha' & anteriorização \\
\hline & $\mathrm{z}$ & ma[z]isterio magistério' & (Bonifácio 2019) \\
\hline
\end{tabular}

Bonifácio (2019) interpreta a variação observada acima entre o português do Brasil e o português ticuna como consequência de processos de posteriorização e anteriorização causados pela interferência da gramática ticuna. Assumimos aqui uma perspectiva não linear para explicar as diferenças existentes entre as duas gramáticas. Na perspectiva não linear, o que torna possível a variação observada no grupo de consoantes fricativas do português de contato é a falta de oposição do traço [anterior] no interior de coronal entre as consoantes africadas /ts, dz/, na gramática do português de contato ticuna. Graças à lacuna existente no interior do sistema ticuna em relação às consoantes obstruintes contínuas, o falante nativo do ticuna bilíngue do português preenche o sistema fonológico da língua de contato com as realizações das africadas fonológicas /ts, dz/, que em termos acústico-articulatórios estariam mais próximas de nossas consoantes fricativas. Assim, o falante controla a oposição existente no interior do traço laríngeo (su/so), responsável por opor /ts, dz/, enquanto produz variação no interior de coronal para as consoantes fricativas. Parece caber então às consoantes /ts, dz/ preencher por meio de suas variantes a lacuna criada no contato entre os sistemas fonológicos consonantais do português do Brasil e da língua ticuna.

A ausência da consoante aproximante labial-dorsal no sistema fonológico do português de Brasil acaba por liberar essa consoante para ocupar as lacunas criadas no sistema fonológico do português de contado graças à interferência fonológica da língua ticuna. À semelhança do que acontece com as africadas /ts, dz/, a aproximante /w/ passa a ocupar no português de contato ticuna o espaço fonológico das consoantes que possuam o traço labial no português do Brasil. 
A consequência é a de que o português de contato ticuna também evidencia o ponto de articulação labial como a principal propriedade da consoante $/ \mathrm{W} /$. A evidência de que a articulação labial é a principal propriedade da aproximante labial-velar é a realização de $[\phi]$ onde no português ocorre $/ \mathrm{kw} /(/ \phi /$ atro 'quatro'). A fricativa $[\phi]$ parece ser a consoante labial não marcada da língua indígena de contato que substitui as consoantes labiais do português tal como demonstram ocorrências como $[\phi]$ ola 'bola'.

A falta de oposição entre consoantes do tipo 'erre' (vibrantes) e 'ele' (não vibrantes) no sistema sonoro consonantal do ticuna também parece ter consequências na gramática do português de contato indígena. $\mathrm{O}$ português do Brasil é uma língua que opõe consoantes vibrantes e laterais seja no onset simples (/r/ua 'rua' versus /l/ua 'lua'; ca/r/o 'caro' versus ca/l/o 'calo'), seja no onset complexo (in/fl/ação 'inflação' versus in/fr/ação 'infração'). A ausência de consoantes laterais no PT e a proximidade acústico-articulatória entre essas consoantes e as vibrantes ${ }^{10}$ parece ser a explicação para a ocorrência de variantes como esco[r]a 'escola'; exemp[r]o 'exemplo'. Bonifácio trata essas ocorrências como consequência da interferência do sistema fonológico da língua ticuna no português de contato. Particularmente, neste caso, a interferência da gramática da língua nativa na gramática da língua estrangeira produz o fenômeno fonológico chamado de rotacismo, que, na mesma proporção em que é bastante popular, também é bastante estigmatizado no português do Brasil. O fato de os falantes estarem produzindo termos linguísticos que refletem um fenômeno gramatical da língua alvo poderia implicar em princípio que adquiriram uma regra fonológica variável da L2, se não fosse o fato de o contato com a gramática ticuna também favorecer o fenômeno de rotacismo no português indígena. É um desafio determinar quais propriedades sonoras e gramaticais no português de contato com as línguas indígenas são derivadas das gramáticas nativas desses falantes, principalmente quando estamos diante de enunciados linguísticos que parecem refletir propriedades da língua estrangeira. Ao mesmo tempo, não reconhecer a presença de características sonoras e gramaticais das línguas dos primeiros povos no português de contato indígena é mais uma vez reproduzir seu apagamento histórico na participação da língua, sociedade e cultura em favor de uma homogeneidade linguística imaginária nacional.

Assim como ocorre com o sistema consonantal, também é registrada a interferência do sistema sonoro vocálico da língua ticuna no português de contato. A partir de seus estudos com a língua, Soares (1995) apresenta o seguinte quadro, visto em (ii), de vogais fonológicas do ticuna:

10 Não por acaso, as laterais e vibrantes são chamadas de consoantes líquidas pela tradição gramatical greco-latina. Essa denominação comum indica que os gramáticos antigos já percebiam a proximidade natural entre os dois grupos de consoantes. 
(ii) Vogais fonológicas da língua ticuna

\begin{tabular}{|c|c|c|}
\hline $\mathrm{i}$ & $\mathrm{i}$ & $\mathrm{u}$ \\
\hline $\mathrm{e}$ & $\mathrm{a}$ & $\mathrm{o}$ \\
\hline
\end{tabular}

O quadro sonoro vocálico apresentado por Soares (1995) revela que a língua ticuna organiza suas vogais seguindo um sistema retangular simétrico. A propriedade simétrica do sistema é obtida pelas correspondências existentes entre as vogais dorsais /u, o/, [-anterior] /i, a/ e [+anterior] /i, e/ nas mesmas alturas. Já a propriedade retangular tem origem no fato de as vogais constituirem um sistema de duas alturas. $\mathrm{O}$ traço [aberto] é o que nos permite caracterizar esse sistema vocálico como de duas alturas. O quadro a seguir (ver (iii)) tem como objetivo ilustrar como tal traço permite organizar o sistema sonoro vocálico da língua ticuna. Esse quadro mostra que bastam os traços [aberto 1] e [aberto 2] para registrar as duas alturas existentes na língua.

\section{(iii) Traço aberto das vogais da língua ticuna}

\begin{tabular}{|c|c|c|c|}
\hline & $\mathrm{i} / \mathbf{i} / \mathrm{u}$ & $\mathrm{e} / \mathrm{o}$ & $\mathrm{a}$ \\
\hline Aberto 1 & - & - & + \\
\hline Aberto 2 & - & + & + \\
\hline
\end{tabular}

Diferentemente do sistema sonoro de vogais da língua ticuna, a organização do quadro fonológico para as vogais do PB segue um sistema com o modelo triangular. $\mathrm{O}$ sistema triangular com sete vogais se caracteriza também por sua simetria. As vogais fonológicas do português formam assim um sistema triangular com três alturas (alta/i/,/u/, média /e, $\varepsilon /, / \mathrm{o}, \mathrm{o} /$, e baixa /a/), totalmente simétrico, em que as vogais da série anterior possuem uma correspondente na mesma altura, na série posterior (/i, u/, /e, o/ e / $\varepsilon, o /)$. A seguir, em (iv), é mostrado como o traço [aberto] organiza o sistema sonoro vocálico do $\mathrm{PB}$ em três alturas.

\section{(iv) Traço aberto das vogais do PB}

\begin{tabular}{|c|c|c|c|c|}
\hline & $\mathrm{i} / \mathrm{u}$ & $\mathrm{e} / \mathrm{o}$ & $\varepsilon / 0$ & $\mathrm{a}$ \\
\hline Aberto 1 & - & - & - & + \\
\hline Aberto 2 & - & + & + & + \\
\hline Aberto 3 & - & - & + & + \\
\hline
\end{tabular}

As diferenças existentes entre o sistema simétrico retangular do ticuna e o sistema simétrico triangular do português do Brasil estão presentes no português de contato. A interferência do sistema simétrico retangular no português de contato ticuna é registrada pelos dados de Bonifácio (2019), vistos em (2), abaixo: 
(2)

\begin{tabular}{|c|c|c|c|}
\hline PB & PT & Ocorrências & Fenômeno \\
\hline $\mathrm{o}$ & $\mathrm{u}$ & [u]itenta 'oitenta' & \multirow{2}{*}{$\begin{array}{c}\text { alteamento } \\
\text { (Bonifácio 2019) }\end{array}$} \\
\hline $\mathrm{e}$ & $\mathrm{i}$ & escr[i]ver 'escrever' & \\
\hline $\mathrm{u}$ & o & c[o]rso ‘curso' & \multirow{2}{*}{$\begin{array}{c}\text { abaixamento } \\
\text { (Bonifácio 2019) }\end{array}$} \\
\hline $\mathrm{e}$ & $\varepsilon$ & $\mathrm{s}[\varepsilon] \mathrm{co}$ 'seco' & \\
\hline
\end{tabular}

Tal como acontece com a variação encontrada no sistema consonantal, Bonifácio (2019) interpreta a variação observada entre o português do Brasil e o português ticuna como causada pela interferência da gramática nativa sobre a gramática da língua estrangeira. A autora explica essa interferência como consequência dos processos fonológicos de alteamento e abaixamento de vogais.

Acreditamos que as diferenças observadas entre as vogais do PB e do PC possam ser explicadas por meio da diferença na qualidade do grau de abertura entre as vogais dos dois sistemas. O português do Brasil tem três graus de abertura vocálica, enquanto o português de contato ticuna tem dois graus de abertura vocálica. A consequência é a de que o espaço acústico-articulatório entre as vogais dos dois sistemas pode ser responsável por produzir a variação linguística encontrada no PT. A maior distância acústico-articulatória entre as vogais do ticuna, por um lado, e a menor distância acústico-articulatória entre as vogais do $\mathrm{PB}$, por outro lado, podem influenciar a produção das vogais no $\mathrm{PT}$. Como as vogais médio-fechadas do $\mathrm{PB} / \mathrm{e}, \mathrm{o} /$ não possuem o mesmo espaço acústico-articulatório das correspondentes a essas vogais em ticuna, elas podem ser produzidas como as correspondentes altas no PC (escr[i]ver 'escrever'; [u]itenta 'oitenta'), sendo percebidas pelo falante como mais próximas das vogais altas; ou podem ser produzidas como as médio-abertas correspondentes ( $\mathrm{p}[\varepsilon]$ na 'pena'), sendo percebidas pelo falante como mais próximas das vogais abertas. Da mesma forma, nada impede que uma vogal alta do PB seja produzida como uma vogal médio-fechada por não ser tão alta quanto uma vogal do sistema fonológico vocálico do ticuna (c[o]rso 'curso'). A diferença no espaço articulatório entre as vogais das duas línguas em contato é percebida por Bonifácio (2019), ao menos no que diz respeito à vogal central /a/.

\subsection{O português indígena camaiurá}

Os camaiurás são um grupo indígena tradicional das imediações da lagoa do Ipavu (lagoa grande), localizada no Parque do Xingu, região do Alto Xingu, no estado do Mato Grosso (Seki 2000; ISA). A língua camaiurá pertence à família linguística Tupí Guaraní (Tronco Tupí). As línguas da família Tupí- 
Guaraní ocupam vasta extensão territorial em área nacional, destacando-se, por isso, segundo Rodrigues (1994), de outras famílias linguísticas. Ainda segundo Rodrigues, até o século XVI as línguas da família Tupí-Guaraní podiam ser encontradas em praticamente toda a extensão do litoral brasileiro. Atualmente, seus falantes se encontram nos estados do Amazonas, Rondônia, Pará, Amapá, Maranhão, Mato Grosso, Mato Grosso do Sul, São Paulo, Paraná, Santa Catarina, Rio Grande do Sul, Rio de Janeiro e Espírito Santo (ISA 2009). Fora do Brasil, encontram-se na Guiana Francesa, Venezuela, Colômbia, Peru, Bolívia, Paraguai e Argentina (Rodrigues 1994). Com base no conhecimento fonológico, gramatical e lexical das línguas da família Tupí Guaraní, Rodrigues $(2011,1985)$ apresenta uma proposta de classificação interna das línguas dessa família. Em sua proposta de classificação, o camaiurá se destaca por integrar sozinho o subconjunto VII, constituindo assim um membro mais afastado da família.

Um inventário fonológico das consoantes do camaiurá é apresentado por Seki (2000), em sua gramática de referência da língua. Nesse inventário, a autora divide as consoantes em dois subsistemas. No subsistema não sonorante, estão as consoantes oclusivas, africada e fricativas, que se opõem pelo modo e pelo ponto de articulação. Ainda nesse subsistema, as oclusivas velares $/ \mathrm{k}$, $\mathrm{k}^{\mathrm{w}} / \mathrm{e}$ as fricativas glotais $/ \mathrm{h}, \mathrm{h}^{\mathrm{w}} /$ se opõem pelo traço de labial. No subsistema sonorante, estão as consoantes nasais, vibrantes e aproximantes, que também se opõem pelo modo e ponto de articulação. Chama nossa atenção a exclusão do traço [sonoro] do sistema de oposições das consoantes da língua. Com base então em Seki (2000), e nas propriedades do sistema sonoro, organizamos, no quadro em (v), abaixo, nossa proposta de interpretação para as consoantes do camaiurá:

\section{(v) Consoantes fonológicas da língua Camaiurá}

\begin{tabular}{|c|c|c|c|c|c|c|c|c|}
\hline & \multirow[t]{2}{*}{ Labial } & \multicolumn{2}{|c|}{ Coronal } & \multicolumn{2}{|c|}{ Dorsal } & \multicolumn{2}{|c|}{ Laríngeo } \\
\hline & & & [+anterior $]$ & [-anterior] & [-labial] & [+labial] & [-labial] & [+labial] \\
\hline \multirow[t]{2}{*}{ [-contínuo] } & [-nasal] & $\mathrm{p}$ & $\mathrm{t}$ & ts & $\mathrm{k}$ & $\mathrm{k}^{\mathrm{w}}$ & $?$ & \\
\hline & [+nasal] & $\mathrm{m}$ & $\mathrm{n}$ & & $y$ & & & \\
\hline \multirow[t]{2}{*}{ [+contínuo $]$} & & & f & & & & $\mathrm{h}$ & $\mathrm{h}^{\mathrm{w}}$ \\
\hline & & $\mathrm{w}$ & & $\mathrm{j}$ & & & & \\
\hline
\end{tabular}

Ao invés da sonoridade, o quadro fonológico acima apresenta o traço [nasal] como aspecto articulatório mais importante do sistema consonantal. A grande oposição da língua parece ser baseada nesse traço. A oposição oral versus nasal não é uma novidade na família Tupí-Guaraní. Particularmente, observamos em camaiurá um sistema de 14 fonemas em que as consoantes oclusivas se põem 
pelo traço [-nasal] /p, t, ts, $\mathrm{k}, \mathrm{k}^{\mathrm{w}}, \mathrm{P} / \mathrm{e}[+$ nasal $] / \mathrm{m}, \mathrm{n}, \mathrm{y} /$; as consoantes glotais se opõem pelo traço [-contínuo] / $/$ e [+contínuo] $/ \mathrm{h}, \mathrm{h}^{\mathrm{w}} /$; os fonemas dorsallabial $/ \mathrm{k}^{\mathrm{w}} /$ e fricativo-labial $/ \mathrm{h}^{\mathrm{w}} /$ são interpretados como segmentos complexos que se opõem aos seus segmentos simples correspondentes pelo traço [labial]. A falta de funcionalidade da sonoridade no sistema fonológico consonantal do camaiurá é evidenciada no português de contato.

Silva e Silva (1985) investigam as características sonoras do português indígena camaiurá. Para identificar o estágio do desenvolvimento da gramática do português de indígenas da etnia camaiurá, as duas autoras observam o controle da oposição da sonoridade no interior das consoantes oclusivas $/ \mathrm{p}, \mathrm{b}$, $\mathrm{t}, \mathrm{d}, \mathrm{k}, \mathrm{g} / \mathrm{e}$ fricativas /f, v, s, $\mathrm{z}, \int$, 3/. São registrados por elas cinco contextos de ensurdecimento e sonorização das consoantes obstruintes do português de contato camaiurá. Processos de ensurdecimento e sonorização de obstruintes são registrados depois de pausa (['poka] por [b]oca 'boca'; ['be] por [p]e 'pé'); entre vogais ([sã'taKa] por san[d]ália 'sandália'; [sku'da] por escu[t] ar 'escutar'); e no grupo consonantal (['krilu] por [g]rilo 'grilo'; ['prasu] por [b]raço 'braço'). Processos somente de ensurdecimento são registrados no onset silábico simples interno à palavra e não intervocálico (['bahpa] por bar[b]a 'barba'); e antes de ditongo crescente em sílaba átona (['ît $\left.\mathrm{t}^{\mathrm{j}} \mathrm{u}\right]$ por ín[d] io 'índio'). Com base na variação observada, Silva e Silva consideram que, no estágio do processo de desenvolvimento da gramática do português em que se encontravam, os falantes do camaiurá ainda não teriam incorporado a sonoridade como um traço distintivo do sistema consonantal. A alternância entre os processos de sonorização e ensurdecimento nas respostas obtidas para um mesmo termo nos questionários aplicados pelas autoras reforça a ideia de no português de contato camaiurá a sonoridade poder não ser interpretada como um traço distintivo das palavras. A influência sonora da fonologia nativa explica a falta de funcionalidade da sonoridade na língua de contato. Diferentemente do português que possui a sonoridade como um traço distintivo dos subsistemas [-contínuo] e [+contínuo], o camaiurá exclui completamente a funcionalidade desse traço de seu sistema sonoro. A sua falta de funcionalidade explica então o fato de no português camaiurá o falante poder não perceber a sonoridade como um traço que distingue palavras. A falta de oposição entre as obstruintes surdas e sonoras do português de falantes nativos da língua camaiurá é um bom exemplo de influência do contato linguístico, uma vez que as variantes observadas não são registradas em variedades populares do português do Brasil.

\subsection{O português indígena xinguano}

A interferência de padrões gramaticais nativos do camaiurá e das demais línguas indígenas faladas no Parque Nacional do Xingu nas características gramaticais do português é tratada por Emmerich (1987). Em seu estudo, a 
autora propõe um debate acerca da natureza dos mecanismos necessários para se alcançar a proficiência linguística em uma segunda língua. Para tanto, estabelece três graus ou faixas de fluência do português de contato xinguano com base nas propriedades do fenômeno gramatical de número das categorias nome e verbo, esse último investigado pelos fenômenos de concordância verbal da primeira e terceira pessoa do plural. No grau ou faixa de fluência mais baixo do português xinguano, estão os falantes seniores, que, nos primeiros momentos do contato iniciado na década de 1940, eram jovens. No grau ou faixa de fluência intermediário, estão os falantes jovens das aldeias, nascidos após o contato iniciado na década de 1940. Por último, no grau ou faixa de fluência superior do português xinguano, estão os falantes jovens com vínculo empregatício e residentes no Posto Indígena. Os falantes com grau mais baixo de fluência preservariam as características do pidgin introduzido nos primeiros momentos de contato. Já os falantes do grau intermediário e superior de fluência estariam em diferentes momentos de um processo de depidginização.

A incorporação progressiva da categoria gramatical número do verbo e do nome no português de contato xinguano caracterizaria um processo de depidginização. O número é uma categoria gramatical responsável por criar oposições como singular versus plural; singular versus plural versus dual; singular versus plural versus dual versus trial; singular versus plural versus dual versus trial versus quatrial etc., em nomes e pronomes das línguas naturais. As línguas variam em termos tipológicos no que diz respeito à expressão morfossintática dessa categoria e de seu funcionamento nos sistemas gramaticais particulares.

O comportamento tipológico da categoria gramatical número nas línguas naturais é apreendido pelo universal 34 de Greenberg (1963), segundo o qual "Nenhuma língua possui a noção de trial a não ser que possua também o dual. Não há línguas que possuam o dual sem que a noção de plural também esteja presente", e assim sucessivamente. A ideia é a de que a presença da categoria número nas línguas naturais obedeceria a essa hierarquia implicacional.

Tão importante quanto apreender o comportamento gramatical do número é entender o seu funcionamento sintático nas gramáticas particulares. A categoria gramatical número costuma estar presente nas línguas naturais por meio de núcleos funcionais próprios, ou associados a outros núcleos funcionais, possuindo relevância sintática sobre a estrutura da sentença e do sintagma nominal, e relevância semântica sobre a interpretação nocional (referencial e denotativa) de entidades (seres e objetos) extralinguísticas. Em termos morfossintáticos, o número é membro da categoria gramatical determinante e encontra-se associado, assim como outras categorias, ao núcleo funcional D(eterminante). Com base em trabalhos como o de Abney (1987) e Ritter (1995), Peixoto (2011) elabora uma proposta de organização estrutural para as categorias associadas ao núcleo funcional $\mathbf{D}$, vista em (vi): 


\section{(vi) Organização das categorias que compõem os traços-phi no DP}

(a)

$$
\begin{aligned}
& \stackrel{\mathrm{DP}}{\mathrm{D}} \\
& \text { [pessoa] } \\
& \text { [número] } \\
& \text { [gênero] }
\end{aligned}
$$

(b)

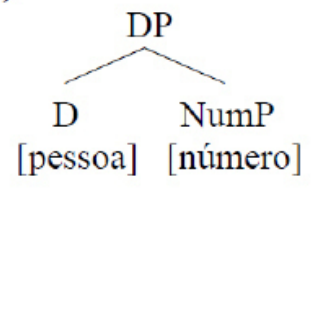

(c)

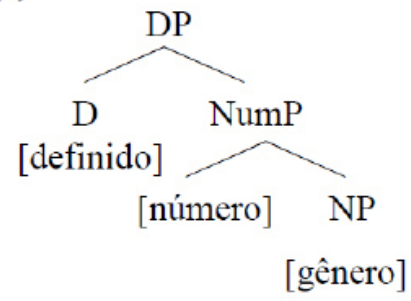

A organização interna e a associação das categorias que constituem os chamados traços-phi em núcleos funcionais permite prever as estruturas vistas acima. Os traços-phi se referem às categorias gramaticais de pesssoa, número e gênero, que costumam ocorrer juntas funcionando como referência ou concordância nas línguas naturais. As configurações acima indicam que, apesar do fato de todo DP poder ser constituído pelo conjunto completo de traçosphi, o mapeamento estrutural desses traços nos núcleos funcionias é variável. Assim, na configuração em (a), os traços [pessoa], [número] e [gênero] são realizados no núcleo D; na configuração em (b), os traços morfossintáticos de pessoa e número se encontram associados a núcleos funcionais diferentes, $\mathbf{D}$ e Num; e, na configuração estrutural em (c), o gênero aparece como um traço que caracteriza o nome.

No português, o número aparece como uma categoria gramatical projetada pelo núcleo D, ou seja, como categoria sem núcleo funcional próprio, nos pronomes de primeira e segunda pessoa (representação (a)). O número configura-se como uma categoria gramatical própria, ou seja, projetada pelo seu próprio núcleo funcional, no pronome de terceira pessoa (representação (b)). Ele também pode funcionar como concordância no interior do sintagma nominal, esse reinterpretado como a projeção de um DP (representação (c)).

Diferentemente, no português xinguano, Emmerich (1987) relata que os mecanismos mais frequentes de expressão da noção semântica de plural são lexicais, e não, gramaticais. Os falantes se utilizariam com bastante frequência de formas lexicais determinadas (xavante, bororo, matipu etc.) e indeterminadas (pessoal, gente, cara, branco, índio etc.) e de marcas morfológicas derivacionais (mulherada, meninada, criançada) como estratégias de pluralização. Essa característica do português xinguano é atribuída pela autora ao pidgin origininal introduzido pelos membros da expedição Roncador-Xingu liderada pelos irmãos Villas Boas. A preferência pela eliminação da morfologia flexional no português para a interação com os indígenas do Alto Xingu teria sido conscientemente feita para promover a aproximação com as línguas nativas no início do contato. Outra preocupação do contato liderado pelos irmãos Villas Boas teria sido a de manter os indígenas afastados da população local sertaneja. O afasmento 
entre indígenas e sertanejos teria como consequência para o contato linguístico a proteção do português xinguano da influência do português regional. $\mathrm{O}$ português xinguano do contato inicial é assim resultado de um processo de pidginização do português, feito com base em uma representação imaginária das línguas dos primeiros povos, apoiada na realidade pelas características compartilhadas pelas línguas indígenas brasileiras. Particularmente, o plural das línguas indígenas de diferentes etnias costuma se apresentar como uma noção semântica dos nomes ou por meio de morfemas sujeitos a exceções lexicais.

Com base em Peixoto (2011), percebemos que o número no português xinguano da fase inicial do contato possui comportamento lexical. O número aparece como um traço semântico de natureza lexical do nome. Sua natureza lexical é evidenciada na medida em que interage com o sentido referencial da palavra. A tendência observada é o uso de termos coletivos para denotar referência genérica ou indefinida (coletivo heterogêneo) ou referência indefinida de pessoas determinadas dentro de um grupo (coletivo homogêneo), neste caso, são usados etnônimos; e naquele, palavras com marcas derivacionais. O traço determinante, responsável pela referência definida e indefinida do sintagma nominal, interage assim com traço de número. O processo de depidginização promovido pelos falantes mais jovens, que segundo Emmerich buscam aproximação com a gramática do português falado culto, é marcado pelo desenvolvimento de regras gramaticais. O número começa a aparecer como uma categoria gramatical não redundante do sintagma determinante, conforme dados de Emmerich ('Os outro pensa, uns meia dúzia que pensa'; 'Os velho mais antigo que manda'), na produção linguística dos falantes com grau intermediário, que correspondem aos jovens da aldeia, e superior de fluência, que correspondem aos jovens do Posto Indígena.

O desenvolvimento das regras de flexão verbal da primeira e terceira pessoa do plural são também evidências do desenvolvimento gramatical do processo de depidginização. A flexão verbal de primeira pessoa do plural se caracteriza por uma grande variabilidade no português xinguano. Entre as variantes registradas por Emmerich (1987) estão: (a) pronome 'nós' e desinência verbal de primeira pessoa do plural ('Aí nós pegamo o carro. Aí nós fomo imbora pra Funai, né?'); (b) pronome nós e desinência de terceira pessoa do singular ('Nós tem assim, nós tem a vida diferente de caraíba ...'); (d) elipse pronominal + desinência verbal de primeira pessoa do plural ('Aí pegamo avião no posto ... Fomo durmi lá no jacaré'); (e) a gente + desinência verbal de primeira pessoa do plural ('Aí a gente fomo na canoa ...'); (f) a gente + terceira pessoa do singular ('Aí ele vem, a gente foi chamá ele pra curá gente'). Emmerich atribui a razão para essa variabilidade ao processo de depidginização. Já a flexão verbal de terceira pessoa do plural aparece de forma esporádica e não redundante na produção 
linguística dos jovens da aldeia ('ele sempre ganha ${ }^{11}$ ' versus 'Num sei que eles perde hoje'), e de forma bastante variável na produção linguística dos jovens do Posto Indígena ('falava' versus 'falavam'; 'fala' versus 'falam'; 'dá' versus 'dão'; 'é' versus 'são'; 'falô' versus 'falaram' etc.) ${ }^{12}$. A flexão verbal de terceira pessoa do plural ainda seria pouco produtiva e estaria em variação com processos lexicais de pluralização.

A diferença entre os traços-phi do verbo e do nome está tão somente no papel que cada subsistema desempenha na sintaxe. No Programa de Estudos da Linguagem da Gramática Gerativa, a flexão verbal é tratada como um efeito de superfície fonética causado pela valoração e apagamento dos traços-phi presentes no núcleo T(empo), e consequente valoração e apagamento do Caso estrutural não interpretável em termos semânticos, presente em termos nominais. Já os traços-phi dos pronomes, que são sempre interpretáveis, já estariam valorados no início da computação sintática e não precisariam ser removidos durante a derivação das sentenças das línguas naturais. No português, os mesmos traçosphi (pessoa e número) que estão presentes na classe dos pronomes também são responsáveis pelo fenômeno de concordância verbal. A emergência progressiva dos traços-phi em diferentes partes (subsistemas) da gramática do português xinguano revela como a gramática da interlíngua evolui de um estágio inicial lexical, marcado pela ocorrência de propriedades linguísticas superficiais de uma língua indígena construída no imaginário, para a reestruturação de aspectos gramaticais da variedade de português em contato com os falantes indígenas.

\subsection{O português indígena huni kuin}

Os huni kuin, autodenominação do grupo caxinauá, habitam as terras interfluviais baixas da Amazônia no Brasil e no Peru. $\mathrm{O}$ caxinauá pertence à família linguística Pano, família constituída por cerca de trinta línguas (algumas das quais já extintas), distribuídas em uma região de fronteira entre a Bolívia, o Peru e o Brasil. No Brasil, a estimativa é a de que sejam faladas doze línguas dessa família, espalhadas pelos estados do Acre, Rondônia e Amazonas. Christino (2015) realiza um estudo acerca das características gramaticais ligadas ao gênero do português de contato com a língua do povo huni kuin.

Como ocorre com outras línguas da família Pano, a informação de gênero gramatical também está excluída de nomes e pronomes do caxinauá. A expressão de gênero se encontra codificada somente nos lexemas /huni/ 'homem'; /ainbu/ 'mulher'; /biní/ 'macho'; /yușan/ 'fêmea', conforme o estatuto natural dos

11 Uma característica da fala dos jovens da aldeia seria ainda uma preferência pelo emprego dos verbos em suas formas não marcadas em termos morfológicos para expressar a noção de plural.

12 A diferença linguística entre os falantes seniores, os falantes jovens da aldeia e os falantes jovens do Posto Indígena estaria mais propriamente na frequência com que as formas marcadas da flexão de plural ocorreriam em sua produção linguística. 
referentes extralinguísticos. A expressão do gênero natural pela gramática da língua é exemplificada abaixo (dados de Camargo, 1999), em (3):

\section{(3) Gênero na língua caxinauá}

\begin{tabular}{|l|l|l|l|}
\hline $\begin{array}{l}\text { a. baki huni } \\
\text { criança homem } \\
\text { 'menino' }\end{array}$ & $\begin{array}{l}\text { b. baki ainbu } \\
\text { criança mulher } \\
\text { 'menina' }\end{array}$ & $\begin{array}{l}\text { c. takada bini } \\
\text { galináceo macho } \\
\text { 'galo' }\end{array}$ & $\begin{array}{l}\text { d. takada fuşan } \\
\text { galináceo fêmea } \\
\text { 'galinha' }\end{array}$ \\
\hline
\end{tabular}

Os dados acima revelam o funcionamento lexical do gênero na língua do povo huni kuin. Em caxianauá, o gênero está presente como uma noção semântica, que, ligada ao mundo natural, é expressa por lexemas próprios. De forma diferente, o português é uma língua que utiliza a oposição entre masculino e feminino em seu sistema gramatical. A natureza gramatical do gênero em português é revelada, por exemplo, pelo funcionamento flexional dessa categoria nos subsistemas pronominal e nominal. A nossa questão então é como as diferenças relacionadas ao gênero no caxainauá e no português do Brasil interferem no contato entre as duas línguas. Christino (2015) investiga a concordância nominal de gênero feminino no interior do sintagma nominal do português de contato huni kuin. A autora identifica como tendência geral do português huni kuin a supergeração das formas não marcadas do masculino. Contudo, formas marcadas do gênero feminino também surgem em certas configurações sintáticas.

Nas construções a seguir, apresentadas por Christino (2015), o gênero no pronome possessivo parece estar refletindo o gênero do possuidor (que é também o falante) e não o da coisa possuída. A esse comportamento gramatical do gênero em estruturas possessivas, Christino chamou de "concordância de gênero orientada para o possuidor" (grifo nosso). Ora, esse comportamento do gênero no português de contato aponta para o funcionamento dêitico-anafórico dessa categoria. Ao buscar como referente um antecedente localizado na situação extralinguística, o gênero emerge como categoria gramatical dêitica, assim como o próprio pronome, no português huni kuin. Assim, ver dados de Christino (2015), em (4):

\section{(4) Gênero como categoria dêitica no português huni kuin ${ }^{13}$}

$\begin{array}{llllll}\text { só } & \text { isso } & \text { que } & \text { é } & \text { meu } & \text { ideia } \\ \text { Only } & \text { this } & \text { relative pronoun } & \text { to } & \text { POSS PRON.1.sg.masc } & \begin{array}{l}\text { idea (fem. noun } \\ \text { head) }\end{array} \\ & & & \text { be.PRES } & & \text { head) }\end{array}$

'That is all that my idea is.'

$13 \mathrm{ART}=$ article $; \mathrm{DEF}=$ defined $; \mathrm{FEM}=$ female $1=$ first person; $\mathrm{MASC}=$ masculine PAST $=$ past; $\mathrm{POSS}=$ possessive; $\mathrm{PRES}=$ present; $\mathrm{PRON}=$ pronoun; $\mathrm{SG}=$ singular. 


$\begin{array}{lllllll}\text { O } & \text { viadinho } & \text { cutucô } & \text { aqui } & \text { no } & \text { meu } & \text { batata da perna } \\ \text { DEF.art. } & \text { little deer } & \text { to poke. } & \text { here } & \text { in } & \text { POSS PRON1sg. } & \begin{array}{l}\text { calf (fem.noun } \\ \text { masc }\end{array} \\ & & \text { PAST } & & & \text { masc. } & \text { head) }\end{array}$

'The little deer poked here in my calf.'

Nas próximas construções, também de Christino (2015), o gênero da categoria determinante parece refletir o gênero do sintagma nominal mais encaixado, ou seja, o sintagma nominal localizado mais à direita, e não do sintagma nominal com o qual forma um constituinte sintático adjacente. A esse comportamento gramatical do gênero no SN complexo, Christino chama de "concordância de gênero orientada pela direita" (grifo nosso). Ao buscar como referente um antecedente não local, situado no sintagma nominal encaixado à direita, o gênero emerge como categoria gramatical catafórica ${ }^{14}$. Assim, ver dados de Christino (2015), em (5):

\section{(5) Gênero como categoria anafórica no português huni kuin}

$\begin{array}{llllll}\text { Os } & \text { cura } & \text { de } & \text { remédio } & \text { É } & \text { assim } \\ \text { DEF.art.masc } & \text { cure (fem. noun } & \text { of } & \text { remedy (masc.noun } & \text { to be.PRES } & \text { so } \\ & \text { head) } & & \text { head) }\end{array}$

'The cures of medicine are so.'

$\begin{array}{lllll}\text { A } & \text { preço } & \text { da } & \text { borracha } & \text { c aiu } \\ \text { DEF art.fem } & \text { price } & \text { of } & \text { rubber (fem.noun head) } & \text { to drop.PAST }\end{array}$

'The rubber price dropped.'

Nos dois tipos de construções do português huni kuin mostrados por Christino (2015), o gênero parece mais como uma categoria gramatical dêiticoanafórica do que meramente a indicação de concordância nominal entre termos da sentença. A natureza dêitico-anafórica da expressão do gênero se apresenta pelo fato de os elementos gramaticais buscarem identificação (interpretação de sua referência) fora de seus domínios locais, seja fora do sintagma nominal, seja fora da sentença. Nesses dois casos, os domínios não locais onde os elementos gramaticais ganham interpretação de sua referência de gênero são a situação extralinguística e o $\mathbf{S N}$ mais encaixado. Atribuímos a natureza dêitico-anafórica do gênero na interlíngua à ausência do mecanismo gramatical de concordância na língua nativa. Diferentemente da concordância, que é um fenômeno altamente especializado na gramática, a dêixis é um processo, sobretudo, contextualmente

14 A referência catafórica, ou seja, identificação com um antecedente à direita, obedece ao padrão tipológico da ordem de constituintes nas línguas da família Pano, e mostra como a ordem de constituintes da sentença se encontra refletida no sintagma nominal. 
situado. A questão que surge é explicar o conhecimento linguístico responsável por no português huni kuin o gênero gramatical funcionar como uma categoria dêitico-anafórica e não como concordância tal como ocorre na gramática da língua alvo.

As línguas da família Pano possuem um dispositivo de Referência Cruzada (Switch Reference). Esse dispositivo é inicialmente reconhecido e investigado por Jacobsen (1967). Nas gramáticas em que ocorre, a Referência Cruzada representa um sistema próprio de flexão verbal, que aparece em sentenças cuja identidade ou não identidade referencial entre dois termos, tipicamente o sujeito ou agente da sentença, é obrigatoriamente acompanhada pela presença de um morfema afixado ao verbo da oração subordinada ou ao verbo mais à esquerda do período coordenado. Nas línguas da família Pano, a Referência Cruzada também é responsável pela expressão do tipo de relação semântico-gramatical estabelecida entre os participantes/argumentos da sentença e pela codificação das informações temporais e/ou aspectuais, por meio de um sistema próprio na morfologia verbal. Trata-se de elementos morfologicamente cumulativos que indicam o tempo em que é realizada a ação da oração subordinada (antes, depois ou simultaneamente à ação da oração principal), e qual o papel semânticosintático $\left(\mathbf{A}, \mathbf{S}, \mathbf{O} / \mathbf{P}^{15}\right)$ dos termos envolvidos.

Nas línguas da família Pano, o fenômeno de Referência Cruzada é bem documentado para o matsés ${ }^{16}$ por Fleck (2003). Nessa língua, a preservação e a mudança de referente da oração principal na oração subordinada são identificadas a partir de morfemas próprios que expressam também relações adverbiais de tempo, razão, condição, propósito e concessão, relações essas estabelecidas em termos semânticos a partir de uma sequência temporal discursiva. No quadro a seguir (em (vii)), buscamos a partir de Fleck a sistematização do fenômeno de Referência Cruzada em matsés. Nesse quadro, fica clara a preferência da língua em juntar os participantes identificados como $\mathbf{S}$ e $\mathbf{A}$ nas relações gramaticais intersentenciais em oposição aos participantes identificados como O. Esse tratamento dado aos participantes da ação/evento ou estado expresso pelo predicado revela um funcionamento sintático nominativo-acusativo do sistema de Referência Cruzada da língua.

15 Os argumentos nucleares da sentença são convencionalmente identificados, conforme seus papéis semântico-sintáticos, como A, S e P/O (Comrie 1989, 1978; Dixon 1994). Vistos como três primitivos da gramática, $\mathbf{S}$ representa o único argumento/participante de um verbo intransitivo, ou o sujeito de verbos intransitivos; A representa o argumento/ participante mais agente de um verbo transitivo, ou o sujeito de verbos transitivos; e $\mathbf{P}$ representa o argumento/participante mais afetado pela ação de um verbo transitivo, ou o constituinte objeto. A escolha entre $\mathbf{P}$ (paciente) e $\mathbf{O}$ (objeto) depende do critério adotado para investigar as relações gramaticais nucleares, isto é, se semântico, se sintático.

16 Língua com falantes no Brasil e Peru. 
(vii) Referência Cruzada na língua matsés

\begin{tabular}{|c|c|c|c|c|}
\hline & \multicolumn{4}{|c|}{$\begin{array}{l}\text { Função semântico-sintática dos } \\
\text { participantes /argumentos }\end{array}$} \\
\hline & Sufixo verbal & Oração subordinada & Oração principal & Tempo \\
\hline $\mathrm{SR}_{1}^{<?>}$ & -ek & $\mathbf{S}, \mathbf{A}$ & $\mathbf{S}$ & Simultâneo \\
\hline $\mathrm{SR}_{2}$ & -kin/-en & $\mathbf{S}, \mathbf{A}$ & $\mathbf{A}$ & Simultâneo \\
\hline $\mathrm{DR}_{3}$ & -nuk & & & Simultâneo \\
\hline $\mathrm{SR}_{4}$ & $-a \int$ & $\mathbf{S}, \mathbf{A}$ & $\mathbf{S}$ & Depois \\
\hline $\mathrm{SR}_{5}$ & $-\int$ un & $\mathbf{S}, \mathbf{A}$ & $\mathbf{A}$ & Depois \\
\hline $\mathrm{SR}_{6}$ & -tanek & $\mathbf{S}, \mathbf{A}$ & $\mathbf{S}$ & Depois \\
\hline $\mathrm{SR}_{7}$ & -tankin & $\mathbf{S}, \mathbf{A}$ & $\mathbf{A}$ & Depois \\
\hline $\mathrm{SR}_{8}$ & -anek & $\mathbf{S}, \mathbf{A}$ & $\mathbf{S}$ & Depois \\
\hline $\mathrm{SR}_{9}$ & -ankin & $\mathbf{S}, \mathbf{A}$ & $\mathbf{A}$ & Depois \\
\hline $\mathrm{DR}^{<?>}{ }_{10}$ & -an & & & Depois \\
\hline $\mathrm{DR}_{11}$ & -bon & & & Depois \\
\hline $\mathrm{SR}_{12}$ & $-\int 0$ & $\mathbf{S}, \mathbf{A}, \mathbf{O}$ & $\mathbf{O}$ & Antes \\
\hline $\mathrm{SR}_{13}$ & -ak & $\mathbf{O}$ & $\mathbf{S}, \mathbf{A}$ & Antes \\
\hline $\mathrm{SR}_{14}$ & -nuk & $\mathbf{S}$ & $\mathbf{O}$ & Limite de tempo \\
\hline $\mathrm{DR}_{15}$ & -teno & & & Antes \\
\hline $\mathrm{SR}_{16}$ & -ek & $\mathbf{S}, \mathbf{A}$ & $\mathbf{S}$ & Depois \\
\hline $\mathrm{SR}_{17}$ & $-\mathrm{nu} \int$ & $\mathbf{S}, \mathbf{A}$ & $\mathbf{S}$ & Antes \\
\hline $\mathrm{SR}_{18}$ & -nun & $\mathbf{S}, \mathbf{A}$ & $\mathbf{S}, \mathbf{A}$ & Antes \\
\hline $\mathrm{SR}_{19}$ & -nuek & $\mathbf{S}, \mathbf{A}$ & $\mathbf{S}$ & Antes \\
\hline $\mathrm{SR}_{20}$ & -nuen & $\mathbf{S}, \mathbf{A}$ & $\mathbf{A}$ & Antes \\
\hline
\end{tabular}

O funcionamento da Referência Cruzada em matsés é exemplificado com os dados de Fleck (2003). As construções em (6) abaixo mostram o seu funcionamento em duas situações. Uma situação (dado (a)) é a que a oração subordinada não tem antecedente na oração principal, expressando um evento que ocorre simultaneamente a essa oração - o que leva ao aparecimento do morfema /-nuk/ no verbo da oração subordinada (badiadnuk ... 'enquanto amanhece ...'). A outra situação (dados (a) e (b)) é a que um participante da oração subordinada identificado como $\mathbf{S}$ ou $\mathbf{A}$ tem como antecedente um participante identificado como $\mathbf{S}$ na oração principal, expressando um evento que ocorre depois do evento dessa oração - o que leva ao aparecimento do morfema /-ek/ no verbo das orações subordinadas (... ueek ... u $\int \mathbf{e k}^{17}$ 'para se deitar ... para dormir'; deby peek t $\int 00 \int$ 'David para comer veio'). Com esses dados, mostramos a correferencialidade (identidade de referência) e a não

17 O sujeito gramatical dos verbos das orações subordinadas tem como referente o antecedente 'o rato da árvore espinhos', que está elíptico na oração principal. 
correferencialidade (não identidade de referência) entre os sujeitos da oração subordinada e da oração principal.

\section{(6) Referência Cruzada: morfemas -nuk e -ek}

(a)

\begin{tabular}{|c|c|c|c|c|}
\hline [badiad-nuc & [[ŞØ & adecbidi & abuc] & [[ushte-ua-aid-no \\
\hline badiad-nuk & $\mathrm{S}$ & adekbidi & abuk & ufte-ua-aid-no \\
\hline vorecer-Enquanto: $\mathbf{D R}_{\mathbf{3}}$ & abs. & igual & aumenta & ninho-vlzr:fazer-paciente.nlzr-lo \\
\hline $\begin{array}{ll}\text { e-ec } & ] \\
\text { e-ek } & \end{array}$ & {[} & $\begin{array}{l}\text { nid-e-c } \\
\text { nid-e-k }\end{array}$ & & $\begin{array}{l}\text { ush-ec]]]] } \\
u \int-\mathbf{e k}^{18}\end{array}$ \\
\hline
\end{tabular}

deitar-propósito:S/A>S ir-não.pass-indic. dormir-propósito:S/A>S ${ }^{19}$

'Enquanto amanhece [o rato da árvore espinhosa] também cresce igualmente para se deitar no ninho que fez para dormir.'

(b)

$\begin{array}{lll}\text { debi- } \varnothing & \text { pe-ec } & \text { cho-o-sh } \\ \text { deby- } \varnothing & \text { pe-ek } & \text { t } 0 \text { o-o- } \int \\ \text { Davy-Abs } & \text { comer-propósito:S/A>S } & \text { vir-pass.-3 }{ }^{\text {a }} \text {. }\end{array}$

'David veio para comer.'

Várias explicações são fornecidas para o fenômeno da Referência Cruzada na literatura. Finer (1985) oferece uma explicação para tal fenômeno no âmbito da Teoria da Regência e Ligação. Basicamente, Finer trata os afixos que indicam correferencialidade entre o sujeito da oração subordinada e o sujeito da oração principal como anáforas. Já os morfemas que indicam a não correferencialidade entre o sujeito da oração subordinada e o sujeito da oração principal são tratados como pronomes. Déchaine \& Wiltschko (2002) também interpretam esse fenômeno sintático a partir de princípios universais da linguagem. Para as autoras, o surgimento de um morfema com propriedades de um DP explica

$18 \mathrm{SR}_{16}$.

$19 \mathbf{S} / \mathbf{A}>\mathbf{S}=$ sujeito $\mathbf{S}$ ou $\mathbf{A}$ da oração subordinada é correferencial com o sujeito $\mathbf{S}$ da oração principal.

20 Pela análise de Fleck (2003), a oração subordinada pode aparecer intercalada, ou vir antes da oração principal, com sujeito preferencialmente elíptico, salvo em situações de ênfase. Assim, em debi peec choosh 'David vem para comer', o constituinte debi 'David' é sujeito da oração principal choosh 'veio'. O caso morfológico é usado como evidência para saber de qual oração (principal ou subordinada) o constituinte é o sujeito gramatical. $\mathrm{O}$ fato de o constituinte debi aparecer no caso absolutivo é evidência de que não pode ser sujeito gramatical da oração subordinada peek 'comer', cujo verbo ocorre com sujeito gramatical no caso ergativo. 
a falta de correferencialidade entre o sujeito da oração principal e o sujeito da oração subordinada. Os morfemas que indicam referência diferente são tratados como DPs e obedecem ao princípio $\mathbf{C}$ da gramática. Já os morfemas que indicam a mesma referência são interpretados como a manifestação pura dos traços-phi ${ }^{21}$. Estes afixos obedecem ao princípio $\mathbf{B}$ da gramática. Finer (1985) e Déchaine \& Wiltschko (2002) analisam os casos de Referência Cruzada como um fenômeno da sintaxe intersentencial sujeito aos princípios universais da gramática. Diferentemente, Roberts (1988) considera que esse mecanismo é mais bem tratado como um dispositivo intersentencial da dêixis discursiva. O fato de esse ser um fenômeno que aparece também em orações coordenadas e leva em consideração informações relacionadas ao hic et nunc da enunciação sustentam a proposta de Roberts. Em resumo, os afixos que indicam correferencialidade entre termos da oração são tratados como anáforas (Finer 1985) ou manifestação pura de traços-phi (Déchaine e Wiltschko 2002), enquanto os morfemas que indicam a não correferencialidade entre termos da oração são tratados como pronomes (Finer 1985) ou mesmo expressões referenciais $^{22}$ (Déchaine e Wiltschko 2002), já Roberts (1988) trata o fenômeno em termos da dêixis discursiva. Essas explicações têm em comum o fato de tratarem a Referência Cruzada como um problema de Ligação da gramática. A Ligação é um princípio que, universalmente presente nas gramáticas das línguas naturais, busca explicar como determinadas estruturas (anáforas, pronomes e expressões referenciais) são interpretadas a partir de referentes presentes dentro e fora da sentença. A busca por referentes dentro e fora da sentença é o que caracteriza o fenômeno da Referência Cruzada, presente em línguas da família Pano, aqui representada pelo matsés.

Trazendo as informações acima a respeito da presença do mecanismo da Referência Cruzada em línguas da família Pano, e das explicações sobre o funcionamento desse mecanismo nas línguas naturais, acreditamos poder compreender melhor o que ocorre com a categoria gramatical gênero no português huni kuin. A nosso ver, o que acontece no português de contato huni kuin é que o falante, ao invés de empregar o gênero como uma categoria flexional de concordância nominal, como ocorre no português brasileiro, o faz como categoria nominal dêitico-anafórica por interferência do fenômeno de Ligação que controla a Referência Cruzada na língua nativa. $O$ gênero é estruturado na interlíngua como uma categoria do sistema de Ligação.

\section{Considerações finais}

Nosso objetivo neste trabalho foi mostrar a presença real das línguas indígenas brasileiras no português do Brasil por meio do contato linguístico.

21 Os pronomes são categorias que são a manifestação pura de traços-phi.

22 Expressões referenciais são DPs. 
Partindo das gramáticas nativas, buscamos demonstrar como as gramáticas das línguas dos povos indígenas estruturam o português falado por esses povos. Com isso, pretendemos promover um resgate histórico das línguas e da presença dos povos indígenas na formação cultural da sociedade brasileira. $\mathrm{O}$ apagamento da cultura e da língua desses povos é resultado de um projeto histórico posto em prática por meio de um processo político de apagamento da heterogeneidade cultural e linguística da sociedade brasileira. A consequência mais clara desse processo é a minorização linguística das línguas faladas pelos povos que, por não conseguirem exercer sua hegemonia, ficam em situação de vulnerabilidade linguística, uma situação que historicamente tem levado ao desaparecimento das línguas dos povos indígenas brasileiros.

O processo histórico de minorização linguística das línguas indígenas pode ser entendido por meio do conceito de colonialidade do ser, desenvolvido por Maldonado-Torres (2007). Ao tratar da extensão das relações de colonialidade na pós-modernidade, o filósofo porto-riquenho mostra a necessidade de uma reflexão a respeito das consequências desse processo na experiência diária dos grupos marginalizados pelo colonialismo, um sistema político-econômico em que nações ou pessoas exercem poder sobre os demais. Reconhecer a presença do repertório verbal de falantes de diferentes etnias como uma contribuição desses povos para o português de contato é parte de um processo de decolonialidade linguística.

Parte do processo de decolonialidade linguística passa pelo resgate da presença das línguas dos primeiros povos no português de contato, pelo respeito às variantes sonoras e gramaticais produzidas pelos membros desses povos, e pela compreensão de que essas variantes são fruto de um processo de desenvolvimento de um conhecimento dos indivíduos e não de uma incompetência linguística. $\mathrm{O}$ respeito e a generosidade é algo essencial para a educação escolar, particularmente, a educação escolar indígena.

\section{Referências}

Abney, Steven Paul. 1987. The English Noun Phrase in its Sentential Aspect. PhD Dissertation, MIT, Cambridge, Massachusetts.

Bloomfield, Leonard. 1933. Language. New Yorker, Henry Holt and Company.

Bonifácio, Ligiane Pessoa dos Santos. 2019. Contato Linguístico Tikuna-Português no Alto Solimões-Amazonas: Um Estudo sobre a Variedade de Português Falada por Professores Tikuna. Tese (Doutorado em Linguística), UFRJ.

Camargo, Eliane. 1999. Elementos da Base Nominal em Caxinauá (Pano). Ms.

Camargo, Eliane. 1991. Phonologie, Morphologie et Sintaxe. Étude Descriptive de la Langue Caxinauá (Pano). Université Paris-Sorbonne.

Chomsky, Noam. 2001. Derivation by Phase. In Kenstowicz, M (editor). Ken Hale: a life in language. MIT Press p. 1-52. 
Chomsky, Noam. 1995. The Minimalist Program. Cambridge, Mass.: MIT Press.

Chomsky, Noam. 1965. Aspectos da Teoria da Sintaxe. Armênio Amado Editor.

Christino, Beatriz. 2015. Gender Agreement in Huni-Kuin Portuguese Noun. Papia. Volume 25(1), p. 77-102, Jan/Jun.

Coelho, Adolpho. 1967. Notas Suplementares. Boletim da Sociedade de Geografia de Lisboa. 1880. Reproduzido em Estudos Lingüísticos Crioulos, 129-196.

Comrie, Bernard. 1989. Language Universals \& Linguistic Typology. 2nd edition. The University of Chicago Press.

Comrie, Bernard. 1978. Ergativity. In Syntatic Typology: Studies in the Phenomenology of Language, ed. W.P. Lehman. Austin: University of Texas Press, p. 329-394.

D’Angelis, Wilmar; Veiga, Juracilda. (orgs.). 1997. Leitura e Escrita em Escolas Indígenas. Encontro de Educação Indígena no $10^{\circ}$ COLE. Campinas, SP: ALB: Mercado das Letras.

Déchaine, Rose-Marie \& Wiltschko, Martina. 2002. Decomposing Pronouns. Linguistic Inquiry, Volume 33, Number 3, Summer.

Dixon, Robert M.W. 1994. Ergativity. Cambridge Studies in Linguistic 69. Cambridge: Cambridge University Press.

Emmerich, Charlotte. 1987. Da Natureza da Variação Lingüística no Português Xinguano. Rio de Janeiro, 76p.

Emmerich, Charlotte. 1984. A Língua de Contato no Alto Xingu. Dissertação de Mestrado Defendida no Âmbito do Programa de Pós-graduação em Linguística/ UFRJ.

Finer, Daniel L. 1985. The Syntax of Switch Reference. Linguistic Inquiry, 16, 35-55.

Fleck, David. 2003. A Grammar of Matsés. PhD. Thesis. Houston, Texas.

Greenberg, Joseph. H (ed.). 1963. Universals of Language. London: MIT Press, pp. $73-113$.

Guy, Gregory Riordan. 1989. On the Nature and Origins of Popular Brazilian Portuguese. Estudios sobre Español de América y Lingüistica Afroamaricana. Bogotá: Instituto Caro y Cuervo, pp. 226-244.

Guy, Gregory Riordan.. 1981a. Linguistic Variation in Brazilian Portuguese. Aspects of Phonology, Syntax and Language History. Tese de Doutorado. Graduate Faculties, University of Pennsylvania, Philadelphia.

Guy, Gregory Riordan.. 1981b. Parallel Variability in American dialects of Spanish and Portuguese. In Sankoff \& Cedergren (Eds.). Variation Omnibus. Edmonton, Linguistic Research Inc, pp. 102-135.

Heye, Jürgen. 1999. Línguas em Contato: Considerações sobre o Bilinguismo e a Bilingualidade. In Investigando a linguagem, pp. 187-198.

Instituto Brasileiro de Geografia e Estatística. https://censo2010.ibge.gov.br/

Instituto Socioambiental. https://pib.socioambiental.org/pt/Povo:Kamaiur\%C3\%A1 
Jacobsen, William Jr. 1967. Switch-reference in Hokan-Coahuiltecan. In Dell Hymes and W. Bittle (eds.): Studies in Southwestern Ethnolinguistics: Meaning and History in the Languages of the American Southwest. The Hague: Mouton, pp. 238-63.

Jeroslow, Elizabeth Helen Mckinney. 1975. Creole Characteristics in Rural Brazilian Portuguese. Paper Presented at the International Conference on Pidgins and Creoles, University of Hawaii.

Maldonado-Torres, Nelson. 2007. On the Coloniality of Being. Cultural Studies, 21:2, $240-270$.

Peixoto, Jaqueline dos Santos 2017a. A Ordem de Constituintes no Português Mbyá Guarani. In As Línguas Tupi: do Vale do Guaporé à Bacia Platina / Marci Fileti Martins, Organizadora. ISBN 978-85-7427-069-2. Formato Ebook: PDF.

Peixoto, Jaqueline dos Santos. 2017b. Categorias Gramaticais em Línguas da Família Pano. Projeto de Estágio Pós-doutoral Apresentado ao Programa de Pós-graduação em Estudos Linguísticos-Poslin da Faculdade de Letras-Fale, Universidade Federal de Minas Gerais-UFMG, Belo Horizonte.

Peixoto, Jaqueline dos Santos. 2013. Aspectos da Variação Sintática e Fonológica do Português como Primeira e Segunda Língua de Falantes Indígenas Brasileiros. Projeto de Pesquisa.

Peixoto, Jaqueline dos Santos. 2011. Os Pronomes e seus Traços em Línguas da Família Pano. Revista Estudos Linguísticos, Belo Horizonte, v. 19, n. 1, pp. 269-320, jan./ jun.

Piggott, Glyne. L. 1992. Variability in Feature Dependence: The Case of Nasality. Natural Language and Linguistic Theory 10:33-77.

Ritter, Elizabeth. 1995. On the Syntactic Category of Pronouns and Agreement. Natural Language and Linguistic Theory 13, pp. 405-443.

Roberts, R. John. 1988. Amele Switch-Reference and the Theory of Grammar. Linguistic Inquiry, Volume 19, Number 1, Winter, p. 45-63.

Rodrigues, Aryon Dall'Igna. 2011. Relações Internas na Família Linguística TupíGuaraní. Revista Brasileira de Linguística Antropológica, Volume 3, Número 2, Dezembro, pp. 233-252.

Rodrigues, Aryon Dall'Igna. 1994. Línguas Brasileiras: Para o Conhecimento das Linguas Indigenas. $2^{\mathrm{a}}$ ed. Edições Loyola, São Paulo.

Rodrigues, Aryon Dall'Igna. 1985. Relações Internas na Família Lingüística TupíGuaraní. Revista de Antropologia, 27/28, 33-53.

Sarmento, Francisco. 2019. O Alto Rio Negro Indígena em mais de Dois Mil Anos de História. Revista Brasileira de Linguística 11(2), pp. 41-72.

Sauter, Kim. 2002. Transfer and Access to Universal Grammar in Adult Second Language Acquisition. Tese de Doutoramento. Holanda: Rijksuuniversiteit Groningen.

Seki, Luci. 2000. Gramática do Kamaiurá: Língua Tupi-Guarani do Alto Xingu. Campinas, SP: Editora da Unicamp; São Paulo, SP: Imprensa Oficial. 502p. 
Selinker, Larry. 1972. Interlanguage. IRAL; International Review of Applied Linguistics in Language Teaching, 10:3, pp. 209-231.

Selinker, Larry. 1972. 1969. Language Transfer. General Linguistics, 9, pp. 67-92.

Silva, Rosa Virginia Mattos e; SILVA, Myrian Barbosa da. 1985. Um traço do Português Kamayurá. Universitas. Ciência. Salvador, (34): 93-107, out./dez.

Soares, Marília Facó. 1995. Núcleo e Coda. A sílaba em Tikuna. In Wetzels, W.L. (org.) Estudos Fonológicos das Línguas Indígenas Brasileiras. Rio de Janeiro: Editora UFRJ, pp. 195-236.

Weireich, Uriel. 1953. Languages in Contact. Nova York: Linguistics Circle of New York.

White, Lydia. 2003. Second Language Acquisition and Universal Grammar. Cambridge, Cambridge University Press. 